\title{
The effect of probiotic supplementation as alternative therapy for NAFLD: a literature review
}

\author{
Muhammad Luthfi Adnan
}

${ }^{1}$ Universitas Islam Indonesia

\begin{abstract}
Background: Non-alcoholic fatty liver disease (NAFLD) is one of the most common liver diseases, influenced by various risk factors associated with metabolic disorders. Currently there is no specific effective treatment for NAFLD. Probiotics have been extensively researched for their health benefit Probiotic Supplementation for NAFLD. Methods: A simple literature review was performed based on searches via PubMed, ScienceDirect and Google Scholar, using the keywords "probiotic," "microbiota," "non-alcoholic fatty liver disease," "metabolic disorder," and "therapy." Results: Research on the use of probiotics for NAFLD demonstrated improvement in liver function and histology. However, the literature is inconsistent regarding the probiotics' influence on the NAFLD risk factors. Probiotics can be an alternative therapy for NAFLD through the ability to modulate the microbiota of the gastrointestinal tract. Conclusion: Probiotics can be an alternative therapy in NAFLD patients, however more extensive studies are needed to ensure the safety of this approach.
\end{abstract}

Keywords: Non-alcoholic fatty liver disease $\cdot$ NAFLD $\cdot$ probiotic $\cdot$ therapy

\section{Citation}

Adnan ML. The effect of probiotic supplementation as alternative therapy for NAFLD: a literature review.

Eur J Transl Clin Med. 2021;4(2):75-85.

DOI: $10.31373 / \mathrm{ejtcm} / 136328$

\section{Introduction}

Non-alcoholic fatty liver disease (NAFLD) is one of the most common causes of chronic liver disease in the world [1]. NAFLD is characterized as $\geq 5 \%$ fat accumulation from hepatocytes with no other secondary diagnostic cause having similar histological characteristics such as viral hepatitis infection, excessive alcohol consumption, other chronic liver diseases (e.g. Wilson's disease, Celiac disease) and drug therapy (e.g. corticosteroids, methotrexate, isoniazid and anti-retrovirals [2-3]. The prevalence of NAFLD has increased in the last 20 years to reach $25.54 \%$ worldwide, with the largest number of cases in the Middle East and South America [4]. NAFLD can cover a wide clinical spectrum in the course of disease severity from non-alcoholic steatohepatitis (NASH), fibrosis, cirrhosis to hepatocellular carcinoma [5]. 
The main risk factors for NAFLD are type 2 diabetes mellitus and the components of metabolic syndrome (e.g. central obesity, dyslipidemia, insulin resistance), while genetic factors, age and alcohol consumption can worsen the progression of NAFLD to fibrosis and cirrhosis [6]. Metabolic syndrome can be caused by a sedentary lifestyle, a diet high in fat and calories and infrequent exercise. NAFLD is also more common in men than women, although post-menopausal women have the same risk of developing NAFLD as men [2]. With the increasing trend of obesity and diabetes, there is a need for improvements in effective management and prevention efforts to address risk factors and reduce the incidence of NAFLD [7].

Currently, there is no definitive pharmacological therapy to treat NAFLD. Instead, patients are offered therapies to reduce the risk of NAFLD, e.g. by increasing insulin sensitivity and decreasing inflammation [8]. Current findings suggest that the microbiota in the gut may influence the course of NAFLD disease [9]. This condition is influenced by an unhealthy diet that affects the development of the gut microbiota and affects the metabolism of nutrients in the gut [10]. Probiotics are one of the supplements that can be used to modify the diet of NAFLD patients [11]. Several studies have shown the effect of probiotics on the gut microbiota in patients with diabetes, obesity, cardiovascular disease and chronic liver disease [12]. This review aims to discuss the effect of the gut microbiota on NAFLD and the role of probiotics on NAFLD.

\section{Material and methods}

A simple literature review was performed. Literature search was carried out from December 2019 to March 2020 using the PubMed, ScienceDirect and Google Scholar search engines and the keywords "probiotic," "microbiota," "non-alcoholic fatty liver disease," "metabolic disorder" and "therapy." The inclusion criteria used were: full-text in English or Indonesian, article published within the last 10 years. Articles in other languages or published earlier than 10 years ago were excluded. The articles included in the analysis were: randomized controlled trials (RCTs), meta-analyses, literature reviews and systematic reviews.

\section{Results}

A total of 13 articles were included in the analysis (see Table 1).

Table 1. Studies on the effects of probiotics in NAFLD patients

\begin{tabular}{|c|c|c|c|c|}
\hline $\begin{array}{c}\text { Author } \\
\text { (year of publish) }\end{array}$ & Type of probiotic & Control & Duration & Result \\
\hline $\begin{array}{l}\text { Aller et al } \\
(2011) \text { [47] }\end{array}$ & $\begin{array}{c}500 \text { million Lactobacillus } \\
\text { bulgaricus and Streptococcus } \\
\text { thermophilus }\end{array}$ & Placebo & 3 months & $\begin{array}{c}\downarrow \text { liver enzymes, } \uparrow \text { cholesterol } \\
\text { levels. There is no significant } \\
\text { change in anthropometrics }\end{array}$ \\
\hline $\begin{array}{l}\text { Vajro et al } \\
(2011)[48]\end{array}$ & Lactobacillus rhamnosus strain GG & Placebo & 8 weeks & $\begin{array}{l}\qquad \downarrow \text { ALT, } \downarrow \text { BMI } \\
\text { and TNF-a were not significant }\end{array}$ \\
\hline $\begin{array}{l}\text { Malaguarnera et al } \\
\qquad \text { (2012) [52] }\end{array}$ & $\begin{array}{l}\text { Bifidobacterium longum } \\
\text { with fructooligosacchaarides }\end{array}$ & $\begin{array}{l}\text { Lifestyle } \\
\text { modification }\end{array}$ & 24 weeks & $\begin{array}{c}\downarrow \text { ALT, AST, total cholesterol, HOMA-IR, } \\
\text { pro-inflammatory cytokines, } \\
\text { steatosis and NASH activity index }\end{array}$ \\
\hline $\begin{array}{l}\text { Alisi et al } \\
(2014) \text { [45] }\end{array}$ & $\begin{array}{l}\text { VSL\#3 (four strain of Lactobacillus } \\
\text { (Lactobacillus acidophilus, } \\
\text { Lactobacillus plantarum, } \\
\text { Lactobacillus casei, and Lactobacillus } \\
\text { delbrueckii subspecies bulgaricus), } \\
\text { three strains of Bifidobacterium } \\
\text { (Bifidobacterium breve, } \\
\text { Bifidobacterium longum } \\
\text { and Bifidobacterium infantis), } \\
\text { and a strain of Streptococcus } \\
\text { (Streptococcus salivarius } \\
\text { subspecies thermophilus)) }\end{array}$ & Placebo & 4 months & $\begin{array}{c}\downarrow \downarrow \text { NAFLD severity, } \downarrow \text { BMI, } \\
\uparrow \text { glucagon-like peptide } 1 \text { (GLP-1) } \\
\text { and activated GLP-1 (aGLP- } 1 \text { ). } \\
\text { There is no significant change } \\
\text { in ALT and triglyceride }\end{array}$ \\
\hline
\end{tabular}




\begin{tabular}{|c|c|c|c|c|}
\hline $\begin{array}{c}\text { Author } \\
\text { (year of publish) }\end{array}$ & Type of probiotic & Control & Duration & Result \\
\hline $\begin{array}{l}\text { Nabavi et al } \\
(2014)[50]\end{array}$ & $\begin{array}{c}\text { Probiotic yogurt } \\
\text { (Lactobacillus bulgaricus, } \\
\text { Streptococcus thermophilus, } \\
\text { Bifidobacterium lactis Bb12 } \\
\text { and Lactobacillus } \\
\text { acidophilus La5) }\end{array}$ & $\begin{array}{l}\text { Convetional } \\
\text { yogurt } \\
\text { (Lactobacil- } \\
\text { lus bulga- } \\
\text { ricus and } \\
\text { Streptococ- } \\
\text { cus thermo- } \\
\text { philus) }\end{array}$ & 8 weeks & $\begin{array}{c}\downarrow \text { ALT, AST, total cholesterol, } \\
\text { and LDL. Changes in serum } \\
\text { glucose, triglycerides, and HDL } \\
\text { were not significant }\end{array}$ \\
\hline $\begin{array}{l}\text { Sepideh et al } \\
(2015)[54]\end{array}$ & $\begin{array}{c}\text { Lactobacillus } \\
\text { casei, Lactobacillus acidophilus, } \\
\text { Lactobacillus rhamnosus, } \\
\text { Lactobacillus bulgaricus, } \\
\text { Bifidobacterium breve, } \\
\text { Bifidobacterium longum, } \\
\text { dan Streptococcusthermophilus }\end{array}$ & Placebo & 2 months & $\begin{array}{c}\downarrow \text { Fasting blood glucose, } \\
\text { insulin, HOMA-IR } \\
\text { and IL- } 6 \text { between groups } \\
\text { with no significant change } \\
\text { in TNF- a level. }\end{array}$ \\
\hline $\begin{array}{c}\text { Manzhalii et al } \\
\text { (2017) [46] }\end{array}$ & $\begin{array}{c}\text { Lactobacillus casei, L. rhamnosus, } \\
\text { L. bulgaricus, Bifidobacterium } \\
\text { longum,Streptococcus } \\
\text { thermophilus and fructooligosac- } \\
\text { charides with low calorie diet }\end{array}$ & $\begin{array}{l}\text { low } \\
\text { calorie } \\
\text { diet }\end{array}$ & 12 weeks & $\begin{array}{c}\downarrow \text { BMI, ALT, AST, total cholesterol. } \\
\text { There is no significant change in } \\
\text { triglycerides, glucose, } \\
\text { and gamma-glutamyl } \\
\text { transferase (GGT) }\end{array}$ \\
\hline $\begin{array}{c}\text { Famouri et al } \\
\text { (2017) [49] }\end{array}$ & $\begin{array}{c}\text { Lactobacillus acidophilus ATCC } \\
\text { B3208, Bifidobacterium lactis } \\
\text { DSMZ 32269, Bifidobacterium } \\
\text { bifidum ATCC SD6576, } \\
\text { Lactobacillus rhamnosus } \\
\text { DSMZ } 21690\end{array}$ & Placebo & 12 weeks & $\begin{array}{c}\downarrow \text { ALT, AST, LDL, triglycerides and } \\
\text { waist circumference. There is no } \\
\text { significant change in BMI } \\
\text { and body weight }\end{array}$ \\
\hline $\begin{array}{l}\text { Asgharian et al } \\
(2017)[51]\end{array}$ & $\begin{array}{l}\text { Lactobacillus casei, } \\
\text { Lactobacillus acidopholus, } \\
\text { Lactobacillus rhamnosus, } \\
\text { Lactobacillus bulgaricus, } \\
\text { Bifidobacterium breve, } \\
\text { Bifidobacterium longum, } \\
\text { Streptococcus thermophiles } \\
\text { and fructooligosaccharides }\end{array}$ & Placebo & 5 months & $\begin{array}{l}\downarrow \downarrow \text { body weight, body fat, } \\
\text { and total cholesterol. There is no } \\
\text { significant change in triglycerides, } \\
\text { fasting blood glucose and HDL-c }\end{array}$ \\
\hline $\begin{array}{l}\text { Behrouz et al } \\
(2017)[53]\end{array}$ & $\begin{array}{c}\text { Lactobacillus casei, Lactobacillus } \\
\text { rhamnosus, Lactobacillus } \\
\text { acidophilus, Bifidobacterium } \\
\text { longum, dan Bifidobacterium brev }\end{array}$ & $\begin{array}{l}\text { Placebo and } \\
\text { prebiotic }\end{array}$ & 12 weeks & $\begin{array}{c}\downarrow \text { leptin serum concentrations, } \\
\text { insulin and HOMA-IR, } \\
\uparrow \text { Quantitative insulin-sensitivity } \\
\text { check index (QUICKI) }\end{array}$ \\
\hline $\begin{array}{l}\text { Kobyliak et al } \\
(2018)[59]\end{array}$ & $\begin{array}{c}\text { Bifidobacterium, } \\
\text { Lactobacillus, Lactococcus, } \\
\text { dan Propionibacterium }\end{array}$ & Placebo & 8 weeks & $\begin{array}{l}\downarrow \text { liver enzyme, fat liver, IL- } 6 \text { and } \\
\text { TNF-a. There is no significant change } \\
\text { in lipid profile and anthropometrics }\end{array}$ \\
\hline
\end{tabular}




\begin{tabular}{|c|c|c|c|c|}
\hline $\begin{array}{c}\text { Author } \\
\text { (year of publish) }\end{array}$ & Type of probiotic & Control & Duration & Result \\
\hline $\begin{array}{l}\text { Ahn et al } \\
\text { (2019) [56] }\end{array}$ & $\begin{array}{l}\text { L. acidophilus CBT LA1, } \\
\text { L. rhamnosus CBT LR5, L. paracasei } \\
\text { CBT LPC5, P. pentosaceus CBT } \\
\text { SL4, B. lactis CBT BL3, } \\
\text { dan B. breve CBT BR3 }\end{array}$ & Placebo & 12 weeks & $\begin{array}{c}\downarrow \text { intrahepatic fat fractions and } \\
\text { visceral fat. There is no significant } \\
\text { change in insulin HOMA-IR, } \\
\text { IL- } 6 \text {, and TNF-a }\end{array}$ \\
\hline $\begin{array}{l}\text { Duseja et al } \\
\text { (2019) [55] }\end{array}$ & $\begin{array}{l}\text { Lactobacillus paracasei DSM } 24733, \\
\text { Lactobacillus plantarum DSM } \\
24730, \text { Lactobacillus acidophilus } \\
\text { DSM } 24735 \text { and Lactobacillus } \\
\text { delbrueckii subsp. bulgaricus DSM } \\
\text { 24734, Bifidobacterium longum } \\
\text { DSM 24736, Bifidobacterium in- } \\
\text { fantis DSM 24737, Bifidobacterium } \\
\text { breve DSM 24732, and Streptococ- } \\
\text { cus thermophilus DSM } 24731\end{array}$ & Placebo & 1 year & $\begin{array}{l}\downarrow \text { hepatocyte ballooning, } \\
\text { lobular inflammation, fibrosis, } \\
\text { NAFLD activity score (NAS), } \\
\text { pro-inflammatory cytokines, } \\
\text { liver enzyme and leptin }\end{array}$ \\
\hline
\end{tabular}

Discussion

\section{Pathophysiology of NAFLD and Effect on Gut Microbiota}

NAFLD is influenced by various metabolic disorders [13]. NAFLD is associated with metabolic disorders resulting from worsening metabolic syndrome, e.g. obesity and insulin resistance [14]. The condition of obesity caused by unhealthy consumption patterns with a diet high in fat and calories plays a role in an increase in insulin resistance in the periphery and an increase in the proliferation of adipose cells in the tissue [15]. In obesity there is an increase in the release of free fatty acids (FFA) and cholesterol due to insulin resistance and causes the liver to increased de novo lipogenesis activity [13]. Increased lipogenesis in the liver then increases fat storage in hepatocyte cells, which in turn causes the liver to undergo steatosis [16].

Obesity can also lead to insulin resistance through increased release of pro-inflammatory tumour necrosis factor (TNF)- $\alpha, C$-reactive protein (CRP), interleukin (IL)-6 cytokines, plasminogen activator inhibitor-1 (PAl-1) and many inflammatory mediators in obese patients [17]. The release of proinflammatory cytokines is caused by hyperplasia and hypertrophy of adipose cells due to excess fat accumulation in adipose cells [18]. Inflammation in obesity interferes with insulin activity through several mechanisms, namely interfering with insulin receptor substrate-1 (IRS-1) signaling which functions as an insulin receptor and peroxisome proliferator-activated receptor $\gamma$ (PPAR $\gamma$ ) function which plays a role in directing fat storage and lipid synthe- sis and FFA levels. through stimulation of lipolysis and an increase in triglycerides [18-20]. Obesity condition also results in increased insulin secretion from $\beta$ cells in the pancreas which is stimulated by increased levels of fatty acids and glucose in the blood [21]. Inflammation and increased insulin production in the pancreas lead to the decrease in insulin receptor sensitivity and hyperinsulinemia [22]. This condition then leads to insulin resistance which in turn results in increased lipogenesis of fat in the liver and increases the risk of NAFLD [16].

Ma et al demonstrated the influence of the gut microbiota in the course of NAFLD disease [9]. In the gut, four main phyla bacteria are consisting of Firmicutes, Bacteroidetes, Actinobacteria, and Proteobacteria with $90 \%$ of the bacterial population consisting of Firmicutes and Bacteroidetes [23]. In the condition of obesity, there is a change in the composition of the intestinal microbiota with changes in the ratio of Firmicutes/Bacteroidetes (F/B ratio) found in NAFLD conditions [24]. Such dysbiosis of the intestinal microbiota can damage the tight junctions in the intestinal epithelium and increase the permeability of the gastrointestinal tract [25]. Increased permeability then results in lipopolysaccharide (LPS) produced from bacteria and parts of bacteria such as DNA and RNA in the intestine to enter the body and liver circulation through the gut-liver axis in the portal vein and activate inflammatory reactions systemically through activation of Toll-like receptors (TLRs) [26]. One of the TLRs that influence the pathophysiology of NAFLD is TLR4 which stimulates the release of proinflammatory cytokines TNF- $\alpha$ and IL-1 $\beta$ through the nuclear factor $\mathrm{k} \beta$ (NF-k $\beta$ ) pathway and activates the body's innate immune system [27]. 
Activation of the innate immune system against NAFLD is influenced by Kupffer cells found in the sinusoid liver and stimulated by LPS from bacteria in the gut [28]. Kupffer cells will produce various types of chemokines and proinflammatory cytokines such as IL-1 $\beta$, IL-6, IL-12 IL-18 and TNF- $\alpha$ which play a role in the formation of reactive oxygen species (ROS) and can cause oxidative stress in hepatocyte cells [15]. Increased production of ROS will then result in mitochondrial dysfunction due to interference with antioxidants in cells and excess lipid peroxidation due to high levels of FFA in the liver so that liver cells are damaged [29]. Also, injury to liver cells due to oxidative stress due to the production of ROS can result in increased disease progression through stimulation of fibrotic cells to liver cells resulting in fibrosis [30].

Dysbiosis in the intestinal microbiota plays an important role in increasing the absorption of monosaccharides in the intestine, accelerating the activity of lipogenesis de novo activity in the liver and increased triglycerides [31]. Intestinal microbiota dysbiosis affects the production of short-chain fatty acids (SCFAs) consisting of acetate, propionate and butyrate [32]. In patients with NAFLD, butyrate levels were lower than acetate and propionate level [32]. Butyrate acts as a source of energy for colonocytes in the intestines that maintain intestinal integrity and improve insulin sensitivity of $\beta$ cells, thereby reducing the number of adipose cells in the body [33]. Meanwhile, acetate and propionate affect gluconeogenesis and lipogenesis which lead to NAFLD [32]. These SCFAs can increase absorption, can stimulate G-protein coupled receptors (GPRs) to increase fat and sugar intake from the intestine and increase storage in the adipose tissue [34]. Also, SCFA can activate carbohydrate response element-binding protein (ChREBP) in the liver and increase lipogenesis [35].

Dysbiosis in the gut microbiota can also result in disorders of choline metabolism [32]. Choline is a type of membrane-forming phospholipid and a precursor to the neurotransmitter acetylcholine [32]. Choline also plays a role in the synthesis of VLDL and the transport of lipids to the liver to prevent fat accumulation in the liver [32]. In the dysbiosis of microbiota, choline obtained from the consumption of animal products can be converted into trimethylamine (TMA), which in the liver is converted into trimethylamine- $\mathrm{N}$-oxide (TMAO) and triggers choline deficiency [36]. In conditions of choline deficiency and elevated TMAO, hepatocyte damage occurs and liver steatosis increases [37]. Choline deficiency also affects the permeability of the intestinal barrier which can increase intestinal bacterial infiltration to the liver via the gut-lung-axis which triggers lipid accumulation and steatosis in the liver [21]. With their findings on an important role in NAFLD gut microbiota modulation via the intestinal microbiota has become a potential therapeutic target for treating NAFLD.

\section{Effect of Probiotics on NAFLD}

Probiotics are defined as "live microorganisms when consumed can provide health benefits to the host" [38]. Probiotics have been widely used in the fermentation of foods such as cheese and yoghurt [39]. Several types of probiotic bacteria from the Lactobacillus, Bifidobacterium, Lactococcus, Streptococcus and Saccharomyces groups have been widely studied for their usefulness in the treatment of diarrhoea-associated with Clostridium difficile, gastroenteritis, irritable bowel syndrome (IBS), Helicobacter pylori infection, and respiratory tract infections [40]. Also, probiotics can be used in metabolic disorder due to their anti-obesity, anti-diabetic, and anti-hyperlipidemic activity [41]. With the benefits of probiotics in the improvement of conditions of metabolic disorders, many studies have shown the benefits of probiotics for NAFLD therapy [42].

The role of probiotics in reducing the risk factors associated with NAFLD has been widely assessed [43]. Obesity is one of the main risk factors for NAFLD [44]. Several human studies have shown probiotics to have anti-obesity effects that are associated with a reduced risk of NAFLD, although other studies have shown weight loss does not correlate with NAFLD improvement [43]. In a study by Alisi et al, administration of VSL \#3 consisting of 8 probiotic strains has a weight loss effect in obese children with NAFLD after probiotic administration along with a reduced risk of progressive severity of NAFLD and liver steatosis [45]. The study by Manzhalii et al also showed decreased BMI accompanied by liver alanine aminotransferase (ALT) and aspartate aminotransferase (AST) enzymes and decreased liver stiffness [46]. However, the relationship between weight loss and improved course of NAFLD does not always have a significant effect. In the studies by Aller et al, Famouri et al and Vajro et al, improvement of hepatic function through decreased ALT and AST enzymes in the probiotic consumption group was not influenced by significant weight loss and cardiovascular risk in NAFLD patients [47-49].

Probiotics also have the benefit of improving lipid profiles in NAFLD patients. A study by Nabavi et al showed an improvement in total cholesterol and low-density lipoprotein cholesterol (LDL) followed by a decrease in liver enzyme levels after 8 weeks, although not followed by changes in triglycerides, serum glucose, and high-density lipoprotein cholesterol (HDL) compared to the control group [50]. The study by Asgharian et al and Manzhalii et al also showed a decrease in total cholesterol, body weight and total body fat in NAFLD patients although there were no significant changes in the levels of $\mathrm{HDL}$, triglycerides, and fasting blood glucose [46, 51]. Also, Asgharian et al noted that in the control group there was an increase in total cholesterol, waist circumference and LDL, thus demonstrating the effect of probiotics to prevent worsening of the disease in NAFLD patients 
[51]. Another study by Famouri et al also showed improvements in the lipid profiles of NAFLD patients although without any significant changes in body weight.[49] However, in the study by Alisi et al, the consumption of probiotics led to insignificant results on triglycerides despite an improvement in the condition of NAFLD patients and a reduction of disease progression [45]. Aller et al also showed no significant improvement in cholesterol levels and other cardiovascular risks after probiotic administration, although there was the improvement in liver function in NAFLD patients [47].

Probiotics can also influence insulin resistance in NAFLD patients. A study by Malaguarnera et al showed that giving probiotics with the addition of fructooligosaccharides can improve insulin resistance with a decrease in the homeostasis model assessment of insulin resistance (HOMA-IR) accompanied by improved levels of liver enzymes, lipids and proinflammatory cytokines in NAFLD patients [52]. The study by Behrouz et al also demonstrated improvement of insulin resistance in NAFLD patients with decreased insulin and HOMA-IR levels and increased insulin sensitivity [53]. The study by Sepideh et al also showed an improvement in the glycemic index accompanied by a decrease in fasting blood glucose and proinflammatory cytokine levels after the administration of probiotics [54]. However, the effects of insulin repair were inconsistent. This was shown in a study by Duseja et al where improvement of hepatic function with decreased hepatocyte ballooning, lobular inflammation, and NAFLD activity score (NAS) did not affect HOMA-IR improvement [55]. The study by Ahn et al and Alisi et al also showed no significant effect of improved HOMA-IR and decreased insulin levels on the improvement of hepatic function and intrahepatic fat $[45,56]$. Although studies on NAFLD-model rats have shown the effect of improving insulin resistance on liver repair in NAFLD, further studies are needed regarding the relationship between NAFLD improvement and insulin resistance in humans [57].

Probiotics also have anti-inflammatory effects in NAFLD patients who have improved liver condition and reduce the risk of disease progression [58]. The study by Malaguarnera et $a l$ and Sepideh et al showed the anti-inflammatory effect of probiotics on the improvement of liver function in NAFLD patients, although in the study of Sepideh et al, the decrease in levels of proinflammatory cytokine TNF- $\alpha$ between groups was not significant in the intervention group there was a significant decrease compared to before the intervention. Studies by Kobyliak et al also demonstrated the effect of lowering pro-inflammatory cytokines on reducing levels of liver enzymes and fat accumulation [59]. However, the results were inconsistent in other studies, e.g. by Vajro et al and Ahn et $a$ in which the anti-inflammatory effect was not significant despite the improvement in liver function and histological features in NAFLD patients $[48,56]$. Although studies in animal models have shown an anti-inflammatory effect related to the course of NAFLD disease, further studies in humans are needed to determine the effectiveness of probiotics in NAFLD.

\section{Effect of Probiotics on NAFLD with Modulation of Gut Microbiota}

Although probiotics improve the liver function in NAFLD patients, the specific mechanism of this effect is unclear [43]. Several studies have shown the effect of probiotics via the repair of tight junctions and the integrity of the barrier in the gut [60-62]. Improvement of barrier integrity by probiotic bacteria in animal studies model NAFLD can reduce the level of liver steatosis by improving choline levels from the gut microbiota which correlates with decreased levels of fat accumulation in the liver and decreased steatosis [6163]. Intestinal barrier repair can also improve the immune response in intestine to inhibit the growth and translocation of harmful bacteria to the liver and reduce the level of inflammation in the liver [36, 64-66].

Improvements in gut barrier integrity also reduce LPS from the gastrointestinal tract [67] which can reduce the level of inflammation in the NAFLD group [64]. Probiotics can reduce the levels of LPS that enter the liver through the portal vein and reduce TLR4 activation which results in activated Kupffer cells and result in hepatocyte cell damage [65]. Decreased levels of LPS and levels of inflammation can also affect the repair of microbiota in the gastrointestinal tract thereby inhibiting lipid disposition and chronic inflammation due to NAFLD [68].

The ability of probiotics to modulate the gastrointestinal microbiota also has anti-obesity effects on NAFLD through weight loss activities, inhibition of lipogenesis and decreased levels of inflammation [69]. Probiotic-mediated weight loss is influenced by the ability of probiotics to change the composition of the gut microbiota by increasing the number of Bacteroides, Bifidobacteria and Lactobacilli bacteria and decreasing the number of Firmicutes bacteria which correlates with weight loss [70-72]. Changes in the composition of the gut microbiota have the effect of decreasing fat accumulation in the liver and decreasing the expression of proteins in the liver that affects lipid and glucose metabolism such as PPARY, PPAR $\alpha$, fatty acids synthase (FAS) and glycogen synthase kinase-3 (GSK-3) [72]. Apart from inhibiting lipogenesis, the antiobesity effect of probiotics also reduces leptin and resistin levels which play a role in fat disposition in the body and affect food intake to lose weight [64, 73-74]. The reduction in lipogenesis and fat accumulation in the body by probiotics also contributes to a decrease in the level of inflammation, which correlates with an increase in insulin sensitivity $[68,74]$.

Several studies have shown that the ability of probiotic bacteria to produce SCFA plays a role in improving the condi- 
tion of patients with NAFLD and of all the SCFAs butyrate has the greatest effect [75]. Butyrate has an anti-inflammatory effect through the regulation of anti-inflammatory cytokines in T cells via GPRs receptors, namely GPR41 and GPR43 so that it can maintain the integrity of the gastrointestinal mucosa and prevent bacterial translocation to blood vessels [33, $68,75-76]$. Several studies have shown the effect of butyrate on decreasing TLR4 expression to inhibit NF-K $\beta$ and release of proinflammatory cytokines in the liver, thereby reducing oxidative stress in the liver and preventing damage to the liver. Butyrate also affects the improvement of function and histology in the liver by increasing insulin sensitivity through the activation of glucagon-like peptide-1 (GLP-1), so that it can reduce the risk factors associated with NAFLD such as obesity and insulin resistance [77].

Although probiotic bacteria have beneficial effects on NAFLD, there are still some limitations to the use of probiotic bacteria as NAFLD therapy [43]. One limitation is that at this time there is no known, specific mechanism by which probiotics can modulate liver repair [43]. Further studies are also needed to ascertain the safety and side effects of using probiotics as NAFLD therapy [78]. Furthermore, although several studies showed improvement in the condition of
NAFLD patients, their small sample sizes make interpretation of results a challenge [79]. Therefore, larger studies with more heterogeneous sample sizes are needed to determine the effectiveness of probiotics as part of NAFLD therapy.

\section{Conclusion}

Probiotics have been extensively researched for their wide-ranging health benefits. Several studies have shown the effect of probiotics on improved liver function and decreased progression of risk factors in NAFLD patients. Although there are no studies regarding the probiotics' specific mechanism of action in NAFLD, the ability of probiotic bacteria to modulate the microbiota in the gastrointestinal tract can lead to improvement in patients with NAFLD. Despite some limitations in the studies, probiotics can be a promising therapy against NAFLD.

\section{Conflict of interest}

There is no conflict of interest from any party.

\section{References}

1. Singh SP, Singh A, Misra D, Misra B, Pati GK, Panigrahi MK, et al. Risk factors associated with Non-Alcoholic Fatty Liver Disease in Indians: a case - control study. J Clin Exp Hepatol [Internet]. 2015 Dec;5(4):295-302. Available from: https:// linkinghub.elsevier.com/retrieve/pii/S0973688315004247

2. Perumpail BJ, Khan MA, Yoo ER, Cholankeril G, Kim D, Ahmed A. Clinical epidemiology and disease burden of nonalcoholic fatty liver disease. World J Gastroenterol [Internet]. 2017 Dec 21;23(47):8263-76. Available from: http://www.wignet. com/1007-9327/full/v23/i47/8263.htm

3. Mitra S, De A, Chowdhury A. Epidemiology of non-alcoholic and alcoholic fatty liver diseases. Transl Gastroenterol Hepatol [Internet]. 2020 Apr;5:16-16. Available from: http://tgh.amegroups.com/article/view/5499/html 2

4. Younossi ZM, Koenig AB, Abdelatif D, Fazel Y, Henry L, Wymer M. Global epidemiology of nonalcoholic fatty liver disease-Meta-analytic assessment of prevalence, incidence, and outcomes. Hepatology [Internet]. 2016 Jul;64(1):73-84. Available from: https://onlinelibrary.wiley.com/doi/10.1002/hep.28431

5. Lindenmeyer CC, McCullough AJ. The natural history of Nonalcoholic Fatty Liver Disease - an evolving view. Clin Liver Dis [Internet]. 2018 Feb;22(1):11-21. Available from: https://linkinghub.elsevier.com/retrieve/pii/S1089326117300648

6. Bellentani S. The epidemiology of non-alcoholic fatty liver disease. Liver Int [Internet]. 2017 Jan;37(October 2016):81-4. Available from: https://onlinelibrary.wiley.com/doi/10.1111/liv.13299

7. Jarvis H, Craig D, Barker R, Spiers G, Stow D, Anstee QM, et al. Metabolic risk factors and incident advanced liver disease in non-alcoholic fatty liver disease (NAFLD): a systematic review and meta-analysis of population-based observational studies. Singal A, editor. PLOS Med [Internet]. 2020 Apr 30;17(4):e1003100. Available from: https://dx.plos.org/10.1371/ journal.pmed.1003100

8. Pennisi G, Celsa C, Spatola F, Dallio M, Federico A, Petta S. Pharmacological therapy of Non-Alcoholic Fatty Liver Disease: what drugs are available now and future perspectives. Int J Environ Res Public Health [Internet]. 2019 Nov 7;16(22):4334. Available from: https://www.mdpi.com/1660-4601/16/22/4334

9. Ma J, Zhou Q, Li H. Gut Microbiota and Nonalcoholic Fatty Liver Disease: insights on mechanisms and therapy. Nutrients [Internet]. 2017 Oct 16;9(10):1124. Available from: http://www.mdpi.com/2072-6643/9/10/1124 
10. Houghton D, Stewart C, Day C, Trenell M. Gut Microbiota and Lifestyle Interventions in NAFLD. Int J Mol Sci [Internet]. 2016 Mar 25;17(4):447. Available from: http://www.mdpi.com/1422-0067/17/4/447

11. Ma Y-Y. Effects of probiotics on nonalcoholic fatty liver disease: a meta-analysis. World J Gastroenterol [Internet]. 2013;19(40):6911. Available from: http://www.wignet.com/1007-9327/full/v19/i40/6911.htm

12. Yoo J, Kim S. Probiotics and prebiotics: present status and future perspectives on metabolic disorders. Nutrients [Internet]. 2016 Mar 18;8(3):173. Available from: http://www.mdpi.com/2072-6643/8/3/173

13. Carr RM, Oranu A, Khungar V. Nonalcoholic Fatty Liver Disease. Gastroenterol Clin North Am [Internet]. 2016 Dec;45(4):639-52. Available from: https://linkinghub.elsevier.com/retrieve/pii/S0889855316300607

14. Godoy-Matos AF, Silva Júnior WS, Valerio CM. NAFLD as a continuum: from obesity to metabolic syndrome and diabetes. Diabetol Metab Syndr [Internet]. 2020 Dec 14;12(1):60. Available from: https://dmsjournal.biomedcentral.com/ articles/10.1186/s13098-020-00570-y

15. Divella R, Mazzocca A, Daniele A, Sabbà C, Paradiso A. Obesity, Nonalcoholic Fatty Liver Disease and adipocytokines network in promotion of cancer. Int J Biol Sci [Internet]. 2019;15(3):610-6. Available from: http://www.ijbs.com/v15p0610.htm

16. Smith GI, Shankaran M, Yoshino M, Schweitzer GG, Chondronikola M, Beals JW, et al. Insulin resistance drives hepatic de novo lipogenesis in nonalcoholic fatty liver disease. J Clin Invest [Internet]. 2020 Feb 4;130(3):1453-60. Available from: https://www.jci.org/articles/view/134165

17. Freire GH de A, Freire IM. Eventos na ciência da informação: agenda 2017 no Brasil. Informação Soc Estud [Internet]. 2017 Aug 25;27(2):14-24. Available from: https://periodicos.ufpb.br/index.php/ies/article/view/35758

18. Chen Z, Yu R, Xiong Y, Du F, Zhu S. A vicious circle between insulin resistance and inflammation in nonalcoholic fatty liver disease. Lipids Health Dis [Internet]. 2017 Dec 16;16(1):203. Available from: http://lipidworld.biomedcentral.com/articles/10.1186/s12944-017-0572-9

19. Honma M, Sawada S, Ueno Y, Murakami K, Yamada T, Gao J, et al. Selective insulin resistance with differential expressions of IRS-1 and IRS-2 in human NAFLD livers. Int J Obes [Internet]. 2018 Sep 1;42(9):1544-55. Available from: http://www. nature.com/articles/s41366-018-0062-9

20. Pawlak M, Lefebvre P, Staels B. Molecular mechanism of PPAR $\alpha$ action and its impact on lipid metabolism, inflammation and fibrosis in non-alcoholic fatty liver disease. J Hepatol [Internet]. 2015 Mar;62(3):720-33. Available from: https:// linkinghub.elsevier.com/retrieve/pii/S016882781400806X

21. Ye J-Z, Li Y-T, Wu W-R, Shi D, Fang D-Q, Yang L-Y, et al. Dynamic alterations in the gut microbiota and metabolome during the development of methionine-choline-deficient diet-induced nonalcoholic steatohepatitis. World J Gastroenterol [Internet]. 2018 Jun 21;24(23):2468-81. Available from: http://www.wignet.com/1007-9327/full/v24/i23/2468.htm

22. Bril F, Lomonaco R, Orsak B, Ortiz-Lopez C, Webb A, Tio F, et al. Relationship between disease severity, hyperinsulinemia, and impaired insulin clearance in patients with nonalcoholic steatohepatitis. Hepatology [Internet]. 2014 Jun;59(6):217887. Available from: https://onlinelibrary.wiley.com/doi/10.1002/hep.26988

23. Nadeau BA, Conjeevaram H. The gut microbiome and nonalcoholic fatty liver disease. Clin Liver Dis [Internet]. 2017 Nov;10(5):116-9. Available from: https://onlinelibrary.wiley.com/doi/10.1002/cld.671

24. Jasirwan COM, Muradi A, Hasan I, Simadibrata M, Rindaldi I. Correlation of gut Firmicutes/Bacteroidetes ratio with fibrosis and steatosis stratified by body mass index in patients with non-alcoholic fatty liver disease. Biosci Microbiota, Food Heal [Internet]. 2021;40(1):50-8. Available from: https://www.jstage.jst.go.jp/article/bmfh/40/1/40 2020-046/ article

25. Brandl K, Schnabl B. Is intestinal inflammation linking dysbiosis to gut barrier dysfunction during liver disease? Expert Rev Gastroenterol Hepatol [Internet]. 2015 Aug 3;9(8):1069-76. Available from: http://www.tandfonline.com/doi/full/1 $\underline{0.1586 / 17474124.2015 .1057122}$

26. Nicoletti A, Ponziani FR, Biolato M, Valenza V, Marrone G, Sganga G, et al. Intestinal permeability in the pathogenesis of liver damage: From non-alcoholic fatty liver disease to liver transplantation. World J Gastroenterol [Internet]. 2019 Sep 7;25(33):4814-34. Available from: https://www.wjgnet.com/1007-9327/full/v25/i33/4814.htm

27. Arslan N. Obesity, fatty liver disease and intestinal microbiota. World J Gastroenterol [Internet]. 2014;20(44):16452. Available from: http://www.wjgnet.com/1007-9327/full/v20/i44/16452.htm

28. Meli R, Mattace Raso G, Calignano A. Role of innate immune response in non-alcoholic fatty liver disease: metabolic complications and therapeutic tools. Front Immunol [Internet]. 2014 Apr 23;5(APR):1-14. Available from: http://journal. frontiersin.org/article/10.3389/fimmu.2014.00177/abstract

29. Cichoż-Lach H. Oxidative stress as a crucial factor in liver diseases. World J Gastroenterol [Internet]. 2014;20(25):8082. Available from: http://www.wjgnet.com/1007-9327/full/v20/i25/8082.htm

30. Jia S, Liu X, Li W, Xie J, Yang L, Li L. Peroxisome proliferator-activated receptor gamma negatively regulates the differentiation of bone marrow-derived mesenchymal stem cells toward myofibroblasts in liver fibrogenesis. Cell Physiol Biochem [Internet]. 2015;37(6):2085-100. Available from: https://www.karger.com/Article/FullText/438567 
31. Campo L, Eiseler S, Apfel T, Pyrsopoulos N. Fatty liver disease and gut microbiota: a comprehensive update. J Clin Transl Hepatol [Internet]. 2019 Mar 28;7(1):1-5. Available from: http://www.xiahepublishing.com/2310-8819/ArticleFullText. aspx?sid=2\&id=10.14218\%2FJCTH. 2018.00008

32. Wang X, Xia J, Jiang C. Role of gut microbiota in the development of non-alcoholic fatty liver disease. Liver Res [Internet]. 2019 Mar;3(1):25-30. Available from: https://linkinghub.elsevier.com/retrieve/pii/S2542568418300187

33. Zhou D, Pan Q, Xin F-Z, Zhang R-N, He C-X, Chen G-Y, et al. Sodium butyrate attenuates high-fat diet-induced steatohepatitis in mice by improving gut microbiota and gastrointestinal barrier. World J Gastroenterol [Internet]. 2017;23(1):60. Available from: http://www.wignet.com/1007-9327/full/v23/i1/60.htm

34. Ang Z, Ding JL. GPR41 and GPR43 in obesity and inflammation - protective or causative? Front Immunol [Internet]. 2016 Feb 1;7(FEB):1-5. Available from: http://journal.frontiersin.org/article/10.3389/fimmu.2016.00028

35. Cuevas-Sierra A, Ramos-Lopez O, Riezu-Boj JI, Milagro FI, Martinez JA. Diet, gut microbiota, and obesity: links with host genetics and epigenetics and potential applications. Adv Nutr [Internet]. 2019 Jan 1;10(suppl_1):S17-30. Available from: https://academic.oup.com/advances/article/10/suppl 1/S17/5307226

36. Cui Y, Wang $Q$, Chang R, Zhou X, Xu C. Intestinal barrier function - non-alcoholic fatty liver disease interactions and possible role of gut microbiota. J Agric Food Chem [Internet]. 2019 Mar 13;67(10):2754-62. Available from: https://pubs.acs. org/doi/10.1021/acs.jafc.9b00080

37. Chen Y, Liu Y, Zhou R, Chen X, Wang C, Tan X, et al. Associations of gut-flora-dependent metabolite trimethylamine- $\mathrm{N}$-oxide, betaine and choline with non-alcoholic fatty liver disease in adults. Sci Rep [Internet]. 2016 May 8;6(1):19076. Available from: http://www.nature.com/articles/srep19076

38. Morelli L, Capurso L. FAO/WHO Guidelines on Probiotics. J Clin Gastroenterol [Internet]. 2012 Oct;46(October):S1-2. Available from: https://journals.Iww.com/00004836-201210001-00002

39. Rezac S, Kok CR, Heermann M, Hutkins R. Fermented foods as a dietary source of live organisms. Front Microbiol [Internet]. 2018 Aug 24;9(AUG). Available from: https://www.frontiersin.org/article/10.3389/fmicb.2018.01785/full

40. Suez J, Zmora N, Elinav E. Probiotics in the next-generation sequencing era. Gut Microbes [Internet]. 2020 Jan 2;11(1):7793. Available from: https://www.tandfonline.com/doi/full/10.1080/19490976.2019.1586039

41. Aggarwal J. Probiotics and their effects on metabolic diseases: an update. J Clin DIAGNOSTIC Res [Internet]. 2013;7(1):1737. Available from: http://www.jcdr.net/article fulltext.asp?issn=0973-709x\&year=2013\&month=January\&volume=7\&issue=1\&page $=173-177 \& i d=2701$

42. Lavekar AS, Raje D V, Lavekar AA. Role of probiotics in the treatment of nonalcoholic fatty liver disease: a meta-analysis. Euroasian J Hepato-Gastroenterology [Internet]. 2017 Dec;7(2):130-7. Available from: https://www.ejohg.com/ doi/10.5005/jp-journals-10018-1233

43. Tang Y, Huang J, Zhang W yue, Qin S, Yang Y xuan, Ren H, et al. Effects of probiotics on nonalcoholic fatty liver disease: a systematic review and meta-analysis. Therap Adv Gastroenterol [Internet]. 2019 Jan 25;12:175628481987804. Available from: http://journals.sagepub.com/doi/10.1177/1756284819878046

44. Pang Q. Central obesity and nonalcoholic fatty liver disease risk after adjusting for body mass index. World J Gastroenterol [Internet]. 2015;21(5):1650. Available from: http://www.wignet.com/1007-9327/full/v21/i5/1650.htm

45. Alisi A, Bedogni G, Baviera G, Giorgio V, Porro E, Paris C, et al. Randomised clinical trial: the beneficial effects of VSL\#3 in obese children with non-alcoholic steatohepatitis. Aliment Pharmacol Ther [Internet]. 2014 Jun;39(11):1276-85. Available from: https://onlinelibrary.wiley.com/doi/10.1111/apt.12758

46. Manzhalii E, Virchenko O, Falalyeyeva T, Beregova T, Stremmel W. Treatment efficacy of a probiotic preparation for non-alcoholic steatohepatitis: a pilot trial. J Dig Dis [Internet]. 2017 Dec;18(12):698-703. Available from: https://onlinelibrary.wiley.com/doi/10.1111/1751-2980.12561

47. Aller R, De Luis DA, Izaola O, Conde R, Gonzalez Sagrado M, Primo D, et al. Effect of a probiotic on liver aminotransferases in nonalcoholic fatty liver disease patients: a double blind randomized clinical trial. Eur Rev Med Pharmacol Sci [Internet]. 2011 Sep;15(9):1090-5. Available from: http://www.ncbi.n/m.nih.gov/pubmed/22013734

48. Vajro P, Mandato C, Licenziati MR, Franzese A, Vitale DF, Lenta S, et al. Effects of Lactobacillus rhamnosus strain GG in pediatric obesity-related liver disease. J Pediatr Gastroenterol Nutr [Internet]. 2011 Jun;52(6):740-3. Available from: https://journals.Iww.com/00005176-201106000-00016

49. Famouri F, Shariat Z, Hashemipour M, Keikha M, Kelishadi R. Effects of probiotics on nonalcoholic fatty liver disease in obese children and adolescents. J Pediatr Gastroenterol Nutr [Internet]. 2017 Mar;64(3):413-7. Available from: https:// journals.Iww.com/00005176-201703000-00017

50. Nabavi S, Rafraf M, Somi MH, Homayouni-Rad A, Asghari-Jafarabadi M. Effects of probiotic yogurt consumption on metabolic factors in individuals with nonalcoholic fatty liver disease. J Dairy Sci [Internet]. 2014 Dec;97(12):7386-93. Available from: https://linkinghub.elsevier.com/retrieve/pii/S0022030214007012 
51. Asgharian A, Mohammadi V, Gholi Z, Esmaillzade A, Feizi A, Askari G. The effect of synbiotic supplementation on body composition and lipid profile in patients with NAFLD: a randomized, double blind, placebo-controlled clinical trial study. Iran Red Crescent Med J [Internet]. 2017 Feb 13;19(4). Available from: https://sites.kowsarpub.com/ircmj/articles/13136.html

52. Malaguarnera M, Vacante M, Antic T, Giordano M, Chisari G, Acquaviva R, et al. Bifidobacterium longum with fructo-oligosaccharides in patients with non alcoholic steatohepatitis. Dig Dis Sci [Internet]. 2012 Feb 8;57(2):545-53. Available from: http://link.springer.com/10.1007/s10620-011-1887-4

53. Behrouz V, Jazayeri S, Aryaeian N, Zahedi MJ, Hosseini F. Effects of probiotic and prebiotic supplementation on leptin, adiponectin, and glycemic parameters in non-alcoholic fatty liver disease: a randomized clinical trial. Middle East J Dig Dis [Internet]. 2017 Jun 21;9(3):150-7. Available from: http://mejdd.org/index.php/mejdd/article/view/1651

54. Sepideh A, Karim P, Hossein A, Leila R, Hamdollah M, Mohammad E G, et al. Effects of multistrain probiotic supplementation on glycemic and inflammatory indices in patients with nonalcoholic fatty liver disease: a double-blind randomized clinical trial. J Am Coll Nutr [Internet]. 2016 Aug 17;35(6):500-5. Available from: https://www.tandfonline.com/doi/full/ 10.1080/07315724.2015.1031355

55. Duseja A, Acharya SK, Mehta M, Chhabra S, Rana S, Das A, et al. High potency multistrain probiotic improves liver histology in non-alcoholic fatty liver disease (NAFLD): a randomised, double-blind, proof of concept study. BMJ Open Gastroenterol [Internet]. 2019 Aug 7;6(1):e000315. Available from: https://bmjopengastro.bmj.com/lookup/doi/10.1136/ bmigast-2019-000315

56. Ahn SB, Jun DW, Kang B-K, Lim JH, Lim S, Chung M-J. Randomized, Double-blind, Placebo-controlled Study of a Multispecies Probiotic Mixture in Nonalcoholic Fatty Liver Disease. Sci Rep [Internet]. 2019 Dec 5;9(1):5688. Available from: http://www.nature.com/articles/s41598-019-42059-3

57. Eslamparast T, Eghtesad S, Hekmatdoost A, Poustchi H. Probiotics and nonalcoholic fatty liver disease. Middle East J Dig Dis [Internet]. 2013 Jul;5(3):129-36. Available from: http://www.ncbi.nlm.nih.gov/pubmed/24829682

58. Gao X, Zhu Y, Wen Y, Liu G, Wan C. Efficacy of probiotics in non-alcoholic fatty liver disease in adult and children: a meta-analysis of randomized controlled trials. Hepatol Res [Internet]. 2016 Nov;46(12):1226-33. Available from: https:// onlinelibrary.wiley.com/doi/10.1111/hepr.12671

59. Kobyliak N, Abenavoli L, Mykhalchyshyn G, Kononenko L, Boccuto L, Kyriienko D, et al. A multi-strain probiotic reduces the fatty liver index, cytokines and aminotransferase levels in NAFLD patients: evidence from a randomized clinical trial. J Gastrointest Liver Dis [Internet]. 2018 Mar 31;27(1):41-9. Available from: https://www.jgld.ro/igld/index.php/igld/ article/view/124

60. Safari Z, Gérard P. The links between the gut microbiome and non-alcoholic fatty liver disease (NAFLD). Cell Mol Life Sci [Internet]. 2019 Apr 25;76(8):1541-58. Available from: http://link.springer.com/10.1007/s00018-019-03011-w

61. Ritze Y, Bárdos G, Claus A, Ehrmann V, Bergheim I, Schwiertz A, et al. Lactobacillus rhamnosus GG protects against non-alcoholic fatty liver disease in mice. Covasa M, editor. PLoS One [Internet]. 2014 Jan 27;9(1):e80169. Available from: https://dx.plos.org/10.1371/journal.pone.0080169

62. Mattace Raso G, Simeoli R, lacono A, Santoro A, Amero P, Paciello O, et al. Effects of a Lactobacillus paracasei B21060 based synbiotic on steatosis, insulin signaling and toll-like receptor expression in rats fed a high-fat diet. J Nutr Biochem [Internet]. 2014 Jan;25(1):81-90. Available from: https://linkinghub.elsevier.com/retrieve/pii/S0955286313002003

63. Schneider K, Mohs A, Kilic K, Candels L, Elfers C, Bennek E, et al. Intestinal Microbiota Protects against MCD Diet-Induced Steatohepatitis. Int J Mol Sci [Internet]. 2019 Jan 14;20(2):308. Available from: http://www.mdpi.com/1422$0067 / 20 / 2 / 308$

64. Al-muzafar HM, Amin KA. Probiotic mixture improves fatty liver disease by virtue of its action on lipid profiles, leptin, and inflammatory biomarkers. BMC Complement Altern Med [Internet]. 2017 Dec 13;17(1):43. Available from: http:// bmccomplementalternmed.biomedcentral.com/articles/10.1186/s12906-016-1540-z

65. Xue L, He J, Gao N, Lu X, Li M, Wu X, et al. Probiotics may delay the progression of nonalcoholic fatty liver disease by restoring the gut microbiota structure and improving intestinal endotoxemia. Sci Rep [Internet]. 2017 May 28;7(1):45176. Available from: http://www.nature.com/articles/srep45176

66. Yan Y, Liu C, Zhao S, Wang X, Wang J, Zhang H, et al. Probiotic Bifidobacterium lactis V9 attenuates hepatic steatosis and inflammation in rats with non-alcoholic fatty liver disease. AMB Express [Internet]. 2020 Dec 29;10(1):101. Available from: https://amb-express.springeropen.com/articles/10.1186/s13568-020-01038-y

67. Zhao Z, Chen L, Zhao Y, Wang C, Duan C, Yang G, et al. Lactobacillus plantarum NA136 ameliorates nonalcoholic fatty liver disease by modulating gut microbiota, improving intestinal barrier integrity, and attenuating inflammation. Appl Microbiol Biotechnol [Internet]. 2020 Jun 26;104(12):5273-82. Available from: https://link.springer.com/10.1007/s00253020-10633-9 
68. Liang Y, Liang S, Zhang Y, Deng Y, He Y, Chen Y, et al. Oral administration of compound probiotics ameliorates HFD-induced gut microbe dysbiosis and chronic metabolic inflammation via the $\mathrm{G}$ protein-coupled Rrceptor 43 in non-alcoholic fatty liver disease rats. Probiotics Antimicrob Proteins [Internet]. 2019 Mar 15;11(1):175-85. Available from: http://link. springer.com/10.1007/s12602-017-9378-3

69. Barathikannan K, Chelliah R, Rubab M, Daliri EB-M, Elahi F, Kim D-H, et al. Gut microbiome modulation based on probiotic application for anti-obesity: a review on efficacy and validation. Microorganisms [Internet]. 2019 Oct 16;7(10):456. Available from: https://www.mdpi.com/2076-2607/7/10/456

70. da Silva ST, dos Santos CA, Bressan J. Intestinal microbiota; relevance to obesity and modulation by prebiotics and probiotics. Nutr Hosp [Internet]. 2013;28(4):1039-48. Available from: http://www.ncbi.nlm.nih.gov/pubmed/23889619

71. Porras D, Nistal E, Martínez-Flórez S, González-Gallego J, García-Mediavilla MV, Sánchez-Campos S. Intestinal Microbiota Modulation in Obesity-Related Non-alcoholic Fatty Liver Disease. Front Physiol [Internet]. 2018 Dec 18;9(December):1-21. Available from: https://www.frontiersin.org/article/10.3389/fphys.2018.01813/full

72. Zhong H, Abdullah, Deng L, Zhao M, Tang J, Liu T, et al. Probiotic-fermented blueberry juice prevents obesity and hyperglycemia in high fat diet-fed mice in association with modulating the gut microbiota. Food Funct [Internet]. 2020;11(10):9192-207. Available from: http://xlink.rsc.org/?DOI=DOFO00334D

73. Savcheniuk O, Kobyliak N, Kondro M, Virchenko O, Falalyeyeva T, Beregova T. Short-term periodic consumption of multiprobiotic from childhood improves insulin sensitivity, prevents development of non-alcoholic fatty liver disease and adiposity in adult rats with glutamate-induced obesity. BMC Complement Altern Med [Internet]. 2014 Dec 16;14(1):247. Available from: $\underline{h t t p: / / b m c c o m p l e m e n t a l t e r n m e d . b i o m e d c e n t r a l . c o m / a r t i c l e s / 10.1186 / 1472-6882-14-247 ~}$

74. Falcinelli S, Rodiles A, Hatef A, Picchietti S, Cossignani L, Merrifield DL, et al. Influence of probiotics administration on gut microbiota core. J Clin Gastroenterol [Internet]. 2018 Nov;52(Supplement 1):S50-6. Available from: https://journals.Iww. com/00004836-201811001-00010

75. Canfora EE, Meex RCR, Venema K, Blaak EE. Gut microbial metabolites in obesity, NAFLD and T2DM. Nat Rev Endocrinol [Internet]. 2019 May 22;15(5):261-73. Available from: http://www.nature.com/articles/s41574-019-0156-z

76. Ye J, Lv L, Wu W, Li Y, Shi D, Fang D, et al. Butyrate protects mice against methionine-choline-deficient diet-induced non-alcoholic steatohepatitis by improving gut barrier function, attenuating inflammation and reducing endotoxin levels. Front Microbiol [Internet]. 2018 Aug 21;9(August):1-16. Available from: https://www.frontiersin.org/article/10.3389/ fmicb.2018.01967/full

77. Zhou D, Chen Y-W, Zhao Z-H, Yang R-X, Xin F-Z, Liu X-L, et al. Sodium butyrate reduces high-fat diet-induced non-alcoholic steatohepatitis through upregulation of hepatic GLP-1R expression. Exp Mol Med [Internet]. 2018 Dec 3;50(12):1-12. Available from: http://www.nature.com/articles/s12276-018-0183-1

78. Xie C, Halegoua-DeMarzio D. Role of Probiotics in Non-alcoholic Fatty Liver Disease: Does Gut Microbiota Matter? Nutrients [Internet]. 2019 Nov 19;11(11):2837. Available from: https://www.mdpi.com/2072-6643/11/11/2837

79. Koopman N, Molinaro A, Nieuwdorp M, Holleboom AG. Review article: can bugs be drugs? The potential of probiotics and prebiotics as treatment for non-alcoholic fatty liver disease. Aliment Pharmacol Ther [Internet]. 2019 Sep;50(6):628-39. Available from: $\underline{\text { https://onlinelibrary.wiley.com/doi/10.1111/apt.15416 }}$ 